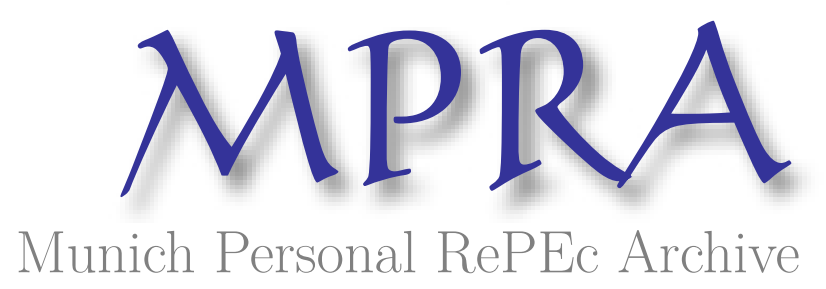

\title{
The impact of ICT on educational performance and its efficiency in selected EU and OECD countries: a non-parametric analysis
}

\author{
Aristovnik, Aleksander \\ University of Ljubljana, Faculty of Administration, Slovenia
}

1 July 2012

Online at https://mpra.ub.uni-muenchen.de/39805/

MPRA Paper No. 39805, posted 03 Jul 2012 13:05 UTC 


\title{
THE IMPACT OF ICT ON EDUCATIONAL PERFORMANCE AND ITS EFFICIENCY IN SELECTED EU AND OECD COUNTRIES: A NON- PARAMETRIC ANALYSIS
}

\author{
Aleksander Aristovnik \\ University of Ljubljana, Slovenia \\ aleksander.aristovnik@fu.uni-lj.si
}

\begin{abstract}
The purpose of the paper is to review some previous researches examining ICT efficiency and the impact of ICT on educational output/outcome as well as different conceptual and methodological issues related to performance measurement. Moreover, a definition, measurements and the empirical application of a model measuring the efficiency of ICT use and its impact at national levels will be considered. For this purpose, the Data Envelopment Analysis (DEA) technique is presented and then applied to selected EU-27 and OECD countries. The empirical results show that the efficiency of ICT, when taking educational outputs/outcomes into consideration, differs significantly across the great majority of EU and OECD countries. The analysis of the varying levels of (output-oriented) efficiency (under the VRSTE framework) shows that Finland, Norway, Belgium and Korea are the most efficient countries in terms of their ICT sectors. Finally, the analysis finds evidence that most of the countries under consideration hold great potential for increased efficiency in ICT and for improving their educational outputs and outcomes.
\end{abstract}

Keywords: Information and Communication Technology (ICT), education, performance, efficiency, DEA, EU, OECD

\section{INTRODUCTION}

Information and communication technology (ICT) is one of the most important driving forces promoting economic growth in the economy. However, there is less of a consensus among economists on whether the impact of ICT also stems from higher total factor productivity (TFP) growth and improved efficiency of production (due to a better educated population). 
During the last two decades countries have invested heavily in ICT. Indeed, the use of ICT in education and training has been a key priority in most EU and OECD countries in the last decade, although progress has been uneven. ICT has had a major impact on the education sector, on organisation and on teaching and learning methods. Yet there are considerably different ICT expenditure levels within and between countries, as well as between institutions within countries. In some countries schools have embedded ICT into the curriculum, and demonstrate high levels of effective and appropriate ICT use to support teaching and learning across a wide range of subject areas. However, in other countries schools are in the early phase of adopting ICT, characterised by important enhancements of the learning process, some developments of e-learning (ICT-enabled learning), but without any profound improvements in learning and teaching (Balanskat et al., 2006).

One puzzling question concerns the effective impact of these technologies on educational outputs and outcomes. As ICTs are being increasingly used in education, indicators to monitor their impact and demonstrate accountability to funding sources and the public are ever more needed. Indicators are required to show the relationships between technology use and educational performance. There is also a need to show that education should be seen as using technology not only as an end in itself, but as a means to promote creativity, empowerment and equality and produce efficient learners and problem solvers. Many academic researchers have tried to answer this question at theoretical and empirical levels. They have faced two main difficulties. On one hand, student performance is hard to observe and there is still confusion about its definition. On the other, ICT entails evolving technologies and their effects are difficult to isolate from their environment. Consequently, the relationship between the use of ICT and educational performance is unclear, and contradictory results are presented in the literature (Youssef and Dahmani, 2008).

Accordingly, the paper's purpose is to discuss and review some previous researches on ICT efficiency and ICT's impact on educational outcomes as well as different conceptual and methodological issues related to measuring performance in education. Moreover, a definition, measurements and an empirical application of a model measuring the efficiency of ICT at national levels will be considered, with a special focus on educational variables as outputs/outcomes. In this context, the Data Envelopment Analysis (DEA) technique will be presented and then applied to selected EU-27 and OECD countries. 
The paper is structured as follows: first, a brief survey of the literature relating to ICTs and their impact on education performance is presented, then the methodology is established and the specifications of the models are defined. The next section outlines the results of the nonparametric efficiency analysis and presents partial correlation coefficients in order to assess the impact of ICT on educational performance. The final section provides concluding remarks and some policy implications.

\section{LITERATURE REVIEW}

Many theoretical and empirical efforts have been made to assess the impact of ICT on in educational performance in various settings. Recent approaches to evaluating ICT in education often only focus on a few aspects such as input, output and outcome/impact. The use of indicators can help assess how the input (e.g. monetary, infrastructure, resources) relates to the impact. However, an evaluation must consider different stages in the implementation process and analyse changes in the culture of the school system - at the micro level (pupils) as well as at the meso (institutions/schools) and macro (national) levels. At national and institutional levels, educational policies and regulations have been established to support the educational use of ICT. In school and classroom settings, teachers and school administrators are attempting to find the best ways to harness ICT technology to support their teaching and students' success. However, accomplishments that are convincingly the result of the direct causal impact of ICT use are not always easily identifiable (Kang et al., 2008).

Currently, there is a significant number of initiatives to assess and monitor the efficiency of ICT use and its impact on education. SITES (the second information technology in educational study), sponsored by the International Association for the Evaluation of Educational Achievement (IEA), is an exemplary study which identifies and describes the educational use of ICT across 26 countries in the world. The study explores the use of computers in teaching through sampling teachers, principals and ICT responsibility in schools. While it does not look into student achievement, it does look at the perceived impact of ICT on students from the teacher's perspective (Pelgrum and Anderson, 1999; Kozma, 2003). Moreover, Balanskat et al. (2006) reviewed several studies on the impact of ICT on schools in Europe. They conclude that the evidence is scarce and comparability is limited. Each study employs a different methodology and approach, and comparisons between countries must be made cautiously. In addition, in several other studies (see Yusuf, \& Afolabi, 2010; Shaikh, 2009; Jayson, 2008; Shaheeda et al., 2007) it is argued that ICT helps to 
improve the quality of learning and educational outcomes. Some other surveys (e.g., Iqbal, and Ahmed, 2010; Hameed, 2006; Amjad, 2006; Khan, and Shah, 2004) argue that, in order to be successful, a country should improve its education system by implementing effective and robust ICT policies.

In contrast, Trucano (2005) reviews a series of studies on ICT's impact on schools and concludes that the impact of ICT use on learning outcomes is unclear. Moreover, Cox and Marshall (2007) point out that ICT studies and indicators do not demonstrate solid effects. Empirica (2006) also explores the access and use of ICT in European schools in 2006. It presents information for $25 \mathrm{EU}$ member states, Norway and Iceland, but does not look into student results so it is impossible to study this important aspect of ICT impact. Machin et al. (2006) state that, while there is a clear case for using ICT to enhance the computer skills of students, the role of technology-enhanced learning (TEL) is more controversial (Machin et al., 2006). There is neither a strong and well-developed theoretical case nor much empirical evidence supporting the expected benefits accruing from the use of ICT in schools since different studies find mixed results (Kirkpatrick and Cuban, 1998). Indeed, while Becta (2002) and Kulik (2003) find a positive effect on the use of ICT and educational attainment, researches by Fuchs and Woessman (2004), Leuven et al. (2004) or Goolsbee and Guryan (2002) find no real positive effect of the use of ICT on educational results once other factors, such as school characteristics or socioeconomic background, are taken into account. ${ }^{1}$

A few previous studies on the performance and efficiency of the education sector (at the national level) applied non-parametric methods. For instance, Gupta and Verhoeven (2001) measure the efficiency of education in Africa, Clements (2002) does so for Europe, St. Aubyn (2003) for education spending in the OECD, and Afonso and St. Aubyn (2005, 2006a, 2006b) in OECD countries. Most studies apply the Data Envelopment Analysis (DEA) method, while Afonso and St. Aubyn (2006a) undertake a two-step DEA/Tobit analysis in the context of a cross-country analysis of secondary education efficiency. However, very few recent studies have examined the efficiency of countries in utilising their ICT resources for educational outputs and outcomes and the impact of ICT on education in a particular country, for instance

\footnotetext{
1 Indeed, Kozma (2008) pointed out that 'some studies reveal a positive correlation between the availability of computer access or computer use and attainment, others reveal a negative correlation, whilst yet others indicate no correlation whatsoever between the two'.
} 
in Turkey (Tondeur et al., 2007) and Belgium (Gulbahar, 2008). Since very insightful, crosscountry analyses have rarely been used for ICT policy analysis, the present research addresses this gap in the literature.

\section{METHODOLOGY AND DATA}

The measurement of efficiency generally requires: (a) an estimation of costs; (b) an estimation of output; and (c) a comparison between the two. Applying this concept to ICT activities, we can say, for example, that ICT expenditure is efficient when, given the amount spent, it produces the largest possible benefit for the country's population. ${ }^{2}$ Often efficiency is defined in a comparative sense: the relation between benefits and costs in country $\mathrm{X}$ is compared with that of other countries. If in country $\mathrm{X}$ the benefits exceed the costs by a larger margin than in other countries, then ICT expenditure in country X is considered more efficient. However, the measurement of ICT efficiency is relatively complicated since the comparison and measurement of both costs and benefits may be difficult.

Figure 1 illustrates the link between input, output and outcome, the main components of efficiency and effectiveness indicators. The monetary and non-monetary resources deployed (i.e. the input) produce an output. For example, ICT spending, investment in the broadband network or a baseline computer-pupil ratio (as possible inputs) affects the number of students completing a grade (as a possible output) and national test results (as a possible outcome). The input-output ratio is the most basic measure of efficiency. ${ }^{3}$ However, compared to productivity measurement, the efficiency concept incorporates the idea of the production possibility frontier, which indicates feasible output levels given the scale of operations. The greater the output for a given input or the lower the input for a given output, the more efficient the activity is. Productivity, by comparison, is simply the ratio of outputs produced to the inputs used. On the other hand, effectiveness relates the input or the output to the final objectives to be achieved, i.e. the outcome. The outcome is often linked to welfare or growth objectives and may therefore be influenced by multiple factors (including outputs but also

\footnotetext{
${ }^{2}$ The word benefit is used because economists often distinguish between output and outcome.

${ }^{3}$ When measuring efficiency, a distinction can be made between technical and allocative efficiency. Technical efficiency measures the pure relationship between inputs and outputs taking the production possibility frontier into account. On the other hand, allocative inefficiency occurs if the distribution of particular public sector outputs is not in accordance with personal preferences (Bailey, 2002).
} 
exogenous 'environment' factors). Effectiveness is more difficult to assess than efficiency since the outcome is influenced by political choices.

Figure 1: Conceptual Framework of Efficiency and Effectiveness

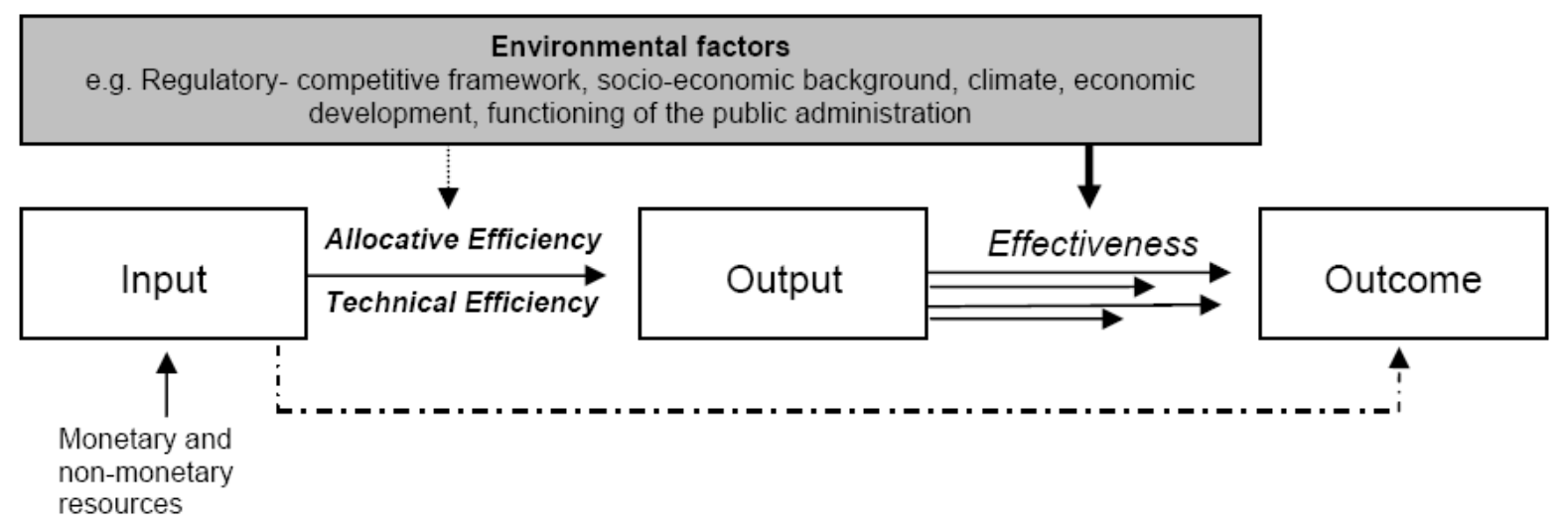

Source: Mandl et al., 2008.

A common non-parametric technique that has recently started to be commonly applied to expenditure analysis is Data Envelopment Analysis (DEA). ${ }^{4}$ DEA is a non-parametric frontier estimation methodology originally introduced by Charnes et al. (1978) that compares functionally similar entities described by a common set of multiple numerical attributes. DEA classifies entities into "efficient" or "performers" versus "inefficient" or "non-performers." According to the DEA framework, inefficiencies are degrees of deviance from the frontier. Input inefficiencies show the degree to which inputs must be reduced for an inefficient country to lie on the efficient practice frontier. Output inefficiencies are the increase in outputs needed for a country to become efficient. If a particular country either reduces its inputs by the inefficiency values or increases its outputs by the amount of inefficiency, it can become efficient; that is, it can obtain an efficiency score of one. The criterion for classification is determined by the location of an entity's data point with respect to the efficient frontier of the production possibility set. The classification of any particular entity can be achieved by solving a linear program (LP).

Various types of DEA models can be used, depending upon the problem at hand. The DEA model we use can be distinguished by the scale and orientation of the model. If one cannot assume that economies of scale do not change, then a variable returns- to-scale (VRSTE) type of DEA model, the one selected here, is an appropriate choice (as opposed to a constant-

\footnotetext{
${ }^{4}$ Originating from Farrell's (1957) seminal work, DEA analysis was originally developed and applied to firms that convert inputs into outputs (see Coelli et al. (2002) for a number of applications).
} 
returns-to-scale, (CRS) model). Furthermore, if in order to achieve better efficiency, economies' priorities are to adjust their outputs (before inputs), then an output-oriented DEA model rather than an input-oriented model is appropriate. The way in which the DEA program computes efficiency scores can be explained briefly using mathematical notation (adapted from Ozcan, 2007). The VRSTE envelopment formulation is expressed as follows:

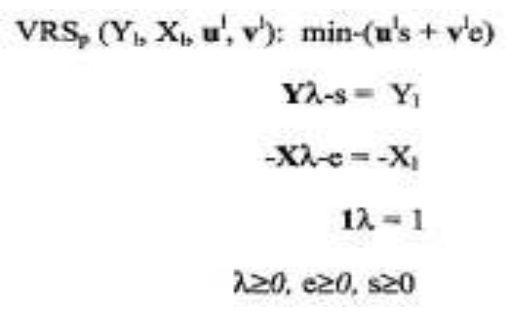

For decision making unit $1, \mathrm{x}_{\mathrm{i} 1} \geq 0$ denotes the $\mathrm{i}^{\text {th }}$ input value, and $\mathrm{y}_{\mathrm{i} 1} \geq 0$ denotes the $\mathrm{r}^{\text {th }}$ output value. $\mathrm{X}_{1}$ and $\mathrm{Y}_{1}$ denote, respectively, the vectors of input and output values. Units that lie on (determine) the surface are deemed efficient in DEA terminology. Units that do not lie on the surface are termed inefficient. Optimal values of variables for decision making unit 1 are denoted by the s-vector $\mathrm{s}^{1}$, the $\mathrm{m}$-vector $\mathrm{e}^{1}$, and the $\mathrm{n}$-vector $\lambda^{1}$.

Although DEA is a powerful optimization technique that can assess the performance of each country, it has certain limitations. When one has to deal with large numbers of inputs and outputs, and a small number of countries are under evaluation, the discriminatory power of the DEA is limited. However, analysts can overcome this limitation by including only those factors (input and output) that provide the essential components of "production", thus avoiding distortion of the DEA results. This is usually done by eliminating one of a pair of factors that are strongly positively correlated with each other.

In the majority of studies using DEA the data are analysed cross-sectionally, with each decision-making unit (DMU) - in this case a country - being observed only once. Nevertheless, data on DMUs are often available over multiple time periods. In such cases, it is possible to perform DEA over time where each DMU in each time period is treated as if it were a distinct DMU. However, in our case the data set for all the tests in the study includes average data for the 1999-2007 period (including PISA 2006 average scores) in order to evaluate long-term efficiency measures as the effects of ICT are characterised by time lags in $27 \mathrm{EU}$ and OECD countries. The program used for calculating the technical efficiencies is the 
DEAFrontier software. The data are provided by the OECD, UNESCO and the World Bank's World Development Indicators database (for Summary statistics see Table 1).

Table 1: Summary Statistics

\begin{tabular}{|c|c|c|c|c|}
\hline & Average & St. Dev. & Min. & Max. \\
\hline \multicolumn{5}{|l|}{ Inputs } \\
\hline $\begin{array}{l}\text { Information and } \\
\text { communication } \\
\text { technology expenditure } \\
(\% \text { of GDP) }\end{array}$ & 6.0885 & 0.9366 & $\begin{array}{c}3.702 \\
(\mathrm{MEX})\end{array}$ & $\begin{array}{c}7.722 \\
(\mathrm{BUL})\end{array}$ \\
\hline $\begin{array}{l}\text { Information and } \\
\text { communication } \\
\text { technology expenditure } \\
\text { (per capita, in USD) }\end{array}$ & $1,682.4$ & 950.9926 & $\begin{array}{c}247.416 \\
(\mathrm{SLK})\end{array}$ & $\begin{array}{c}3,152.654 \\
\text { (USA) }\end{array}$ \\
\hline $\begin{array}{l}\text { Internet users (per } 100 \\
\text { people) }\end{array}$ & 40.3071 & 18.4235 & $\begin{array}{l}9.5133 \\
(\mathrm{MEX})\end{array}$ & $\begin{array}{c}68,43111 \\
\text { (SWE) }\end{array}$ \\
\hline $\begin{array}{l}\text { International Internet } \\
\text { bandwidth (bits per } \\
\text { person) }\end{array}$ & $4,722.9$ & $5,756.232$ & $\begin{array}{c}84.81889 \\
(\mathrm{MEX})\end{array}$ & $\begin{array}{c}21,214.81 \\
(\mathrm{DEN})\end{array}$ \\
\hline \multicolumn{5}{|l|}{ Outputs } \\
\hline $\begin{array}{l}\text { School enrolment, } \\
\text { primary (\% gross) }\end{array}$ & 102.972 & 4.0724 & $\begin{array}{c}98.7438 \\
\text { (GRE) }\end{array}$ & $\begin{array}{c}119,6688 \\
\text { (POR) }\end{array}$ \\
\hline $\begin{array}{l}\text { School enrolment, } \\
\text { secondary (\% gross) }\end{array}$ & 104.6418 & 13.0841 & $\begin{array}{l}79.74 \\
(\mathrm{MEX})\end{array}$ & $\begin{array}{l}133.0922 \\
\text { (BEL) }\end{array}$ \\
\hline $\begin{array}{l}\text { School enrolment, } \\
\text { tertiary (\% gross) }\end{array}$ & 59.2622 & 15.8078 & $\begin{array}{l}22.7644 \\
(\mathrm{MEX})\end{array}$ & $\begin{array}{l}87.75778 \\
\text { (FIN) }\end{array}$ \\
\hline $\begin{array}{l}\text { Teachers per } 100 \text { pupils, } \\
\text { secondary }\end{array}$ & 8.5925 & 1.5601 & $\begin{array}{l}5.2672 \\
(\mathrm{JPN})\end{array}$ & $\begin{array}{c}12.0387 \\
\text { (POL) }\end{array}$ \\
\hline \multicolumn{5}{|l|}{ Outcomes } \\
\hline PISA average (2006) & 491.2264 & 34.6888 & $\begin{array}{l}408.601 \\
(\mathrm{MEX})\end{array}$ & $\begin{array}{l}552.8498 \\
(\mathrm{FIN})\end{array}$ \\
\hline $\begin{array}{l}\text { Labor force with tertiary } \\
\text { education ( } \% \text { of total) }\end{array}$ & 24.7961 & 9.2459 & $\begin{array}{r}10.7429 \\
\text { (POR) }\end{array}$ & $\begin{array}{l}50.475 \\
\text { (USA) }\end{array}$ \\
\hline
\end{tabular}

Sources: World Bank, 2011; UNESCO, 2011; OECD, 2010; own calculations.

The specification of the outputs and inputs is a crucial first step in DEA since the larger the number of outputs and inputs included in any DEA, the higher will be the expected proportion of efficient DMUs, and the greater will be the expected overall average efficiency (Chalos, 1997). Common measures of teaching output in education used in previous studies are based on graduation and/or completion rates (see Johnes, 1996; Jafarov and Gunnarsson, 2008), PISA scores (see Afonso and St. Aubyn, 2005; Jafarov and Gunnarsson, 2008), pupil-teacher ratios and enrolment rates (see Jafarov and Gunnarsson, 2008). Nevertheless, these studies also demonstrate that DEA is an effective research tool for evaluating the efficiency of ICT and its impact on the education sector given the varying input mixes and types and numbers of outputs. 
In this analysis the data set to evaluate the efficiency of ICT includes input/output/outcome data, i.e. information and communication technology expenditure (\% of GDP $)^{5}$, Internet users (per 100 people), teacher-pupil ratio (secondary), school enrolment, all levels (\% gross), labour force with tertiary education (\% of total) and the PISA 2006 average score. Up to 28 countries are included in the analysis (selected EU and OECD countries). Different inputs and outputs/outcomes are tested in four models (see Table 1). In addition, to evaluate the impact of ICT on education, we calculate partial correlation coefficients for different ICT and education variables.

Table 2: Input and output/outcome set for the DEA

\begin{tabular}{|c|c|c|}
\hline Model & Inputs & Outputs/Outcomes \\
\hline I & $\begin{array}{l}\text { Information and communication } \\
\text { technology expenditure }(\% \text { of } \\
\text { GDP })^{1}\end{array}$ & $\circ$ PISA average $(2006)^{2}$ \\
\hline II & $\begin{array}{ll} & \begin{array}{l}\text { Information and communication } \\
\text { technology expenditure ( } \% \text { of }\end{array} \\
\text { GDP) }\end{array}$ & $\begin{array}{ll} & \text { PISA average (2006) } \\
\circ & \text { Labour force with tertiary education }(\% \\
\text { of total }) & 1\end{array}$ \\
\hline III & $\begin{array}{l}\text { Information and communication } \\
\text { technology expenditure (\% of } \\
\text { GDP) } \\
\circ \text { Internet users (per } 100 \text { people) }\end{array}$ & $\begin{array}{ll}\circ & \text { PISA average (2006) } \\
\circ & \text { School enrolment, secondary (\% gross) }{ }^{1} \\
\circ & \text { Teacher-pupil ratio, secondary }{ }^{3}\end{array}$ \\
\hline IV & $\begin{array}{ll} & \text { Information and communication } \\
\text { technology expenditure (\% of } \\
\text { GDP) } \\
\text { Internet users (per } 100 \text { people) }\end{array}$ & $\begin{array}{ll} & \text { PISA average (2006) } \\
\circ & \text { School enrolment, primary (\% gross) }{ }^{1} \\
\circ & \text { School enrolment, secondary (\% gross) } \\
\circ & \text { School enrolment, tertiary (\% gross) }{ }^{1}\end{array}$ \\
\hline
\end{tabular}

Sources: ${ }^{1}$ World Bank; ${ }^{2}$ UNESCO; ${ }^{3}$ OECD.

\section{EMPIRICAL RESULTS}

To see whether ICT has any impact on educational outputs and outcomes, we calculate the partial correlations between different variables, while controlling for the other(s) variable(s) (see Table 3). All educational output and outcome variables show a weak and positive (but not statistically significant) correlation with ICT expenditures (in \% of GDP) when controlling for the number of Internet users. The impact of the number of Internet users is strong and positive as the partial coefficient ranges from 0.53 to 0.71 . An important ICT variable which also influences PISA scores is ICT (per capita) as the partial coefficient

\footnotetext{
${ }^{5}$ ICT expenditures include computer hardware (computers, storage devices, printers, and other peripherals); computer software (operating systems, programming tools, utilities, applications, and internal software development); computer services (information technology consulting, computer and network systems integration, Web hosting, data processing services, and other services); and communications services (voice and data communications services) and wired and wireless communications equipment (World Bank, 2011).
} 
reached 0.53 . There are also some educational output variables which positively influence the PISA scores, such as the teacher-pupil ratio (primary and secondary). Nevertheless, the single most important related variable is the quality of the basic telecommunications infrastructure and broadband penetration. Indeed, a strong ICT infrastructure and its use alone already have an effect on perceived ICT-induced efficiency improvements but does not guarantee a good educational performance in itself. The government and policymakers should not be interested in simply introducing technology into educational institutions, but also in making sure that it is used effectively by teachers and students in order to enhance educational outputs and outcomes.

Table 3: Partial correlation coefficients

\begin{tabular}{|c|c|c|c|c|}
\hline Output/outcome variables & \multicolumn{4}{|c|}{ Input variables } \\
\hline \multirow{2}{*}{$\begin{array}{l}\text { Completion rate - primary } \\
\qquad(\mathrm{n}=24)\end{array}$} & ICT (GDP) & IU & & \\
\hline & 0.012 & -0.09 & & \\
\hline \multirow{2}{*}{$\begin{array}{l}\text { Enrolment rate - } \\
\text { secondary }(n=27)\end{array}$} & ICT (GDP) & IIB & & \\
\hline & 0.005 & $0.684 * * *$ & & \\
\hline \multirow{2}{*}{$\begin{array}{c}\text { Enrolment rate - tertiary } \\
(\mathrm{n}=27)\end{array}$} & ICT (GDP) & $\mathrm{IU}$ & & \\
\hline & 0.083 & $0.709 * * *$ & & \\
\hline \multirow{2}{*}{$\begin{array}{l}\text { Labour force with tertiary } \\
\text { education }(\mathrm{n}=27)\end{array}$} & ICT (GDP) & $\mathrm{IU}$ & & \\
\hline & 0.075 & $0.525 * * *$ & & \\
\hline \multirow{2}{*}{$\begin{array}{l}\text { PISA score } \\
(\mathrm{n}=28)\end{array}$} & ICT (GDP) & $\mathrm{IU}$ & & \\
\hline & 0.128 & $0.687 * * *$ & & \\
\hline \multirow[t]{2}{*}{$\begin{array}{l}\text { PISA scores } \\
\quad(\mathrm{n}=27)\end{array}$} & ICT (p.c.) & $\begin{array}{c}\mathrm{T} / \mathrm{P} \\
\text { (secondary) }\end{array}$ & & \\
\hline & $0.530^{* * *}$ & 0.292 & & \\
\hline \multirow[t]{2}{*}{$\begin{array}{l}\text { PISA scores } \\
\quad(\mathrm{n}=26)\end{array}$} & ICT (p.c.) & $\begin{array}{c}\mathrm{T} / \mathrm{P} \\
\text { (primary) }\end{array}$ & $\begin{array}{c}\mathrm{T} / \mathrm{P} \\
\text { (secondary) }\end{array}$ & \\
\hline & $0.555 * * *$ & -0.268 & $0.339 *$ & \\
\hline \multirow[t]{2}{*}{$\begin{array}{l}\text { PISA scores } \\
\quad(\mathrm{n}=23)\end{array}$} & ICT (GDP) & $\mathrm{IU}$ & $\begin{array}{c}\mathrm{T} / \mathrm{P} \\
\text { (primary) }\end{array}$ & $\begin{array}{r}\text { COMPL } \\
\text { (primary) }\end{array}$ \\
\hline & -0.014 & $0.701 * * *$ & $0.410^{*}$ & -0.1724 \\
\hline
\end{tabular}

Note: $* * *, * * *$ denote significance at the levels of $1 \%, 5 \%$ and $10 \%$, respectively. ICT (GDP) Information and communication technology expenditure (\% of GDP); IU - Internet users (per 100 people); ICT (p.c.) - Information and communication technology expenditure (per capita); T/P Teacher-pupil ratio; IIB - International Internet bandwidth (bits per person); COMPL - completion rate ( $\%$ of relevant age group).

Sources: World Bank, 2011; UNESCO, 2011; OECD, 2010; own calculations.

The results of the output-oriented VRSTE formulation of the DEA analysis (based on Models I-IV in Table 2) suggest a relatively high level of inefficiency of ICT in selected EU and OECD countries and, correspondingly, that there is significant room to improve educational outputs and outcomes (see Table 4). Indeed, the empirical results show that the total number of efficient countries varies significantly from one model to another. There are only two technically efficient countries in Model I, i.e. Finland and Slovakia. However, at $4.424 \%$ of GDP Slovakia has the lowest level of ICT expenditure (in \% of GDP) among all countries in 
the sample. The least efficient nations are Bulgaria, Romania and Greece as a result of their relatively low PISA test scores, ranging from 410 (Romania) to 464 (Greece) (for instance, the EU/OECD group average is around 494). In order to enhance the reliability of the findings, additional inputs and outputs/outcomes were introduced, resulting in models II, III and IV (for details also see Table 2).

Adding another input and output in the form (Model II) of Internet users (per 100 people) and labour force with tertiary education ( $\%$ of total), respectively, the results show Finland, Iceland, Norway, Slovakia and the USA to be the technically most efficient countries. Not surprisingly, increasing the number of outputs/outcomes in a relatively small sample leads to a higher number of efficient countries. In general, the rankings remain relatively stable in comparison to Model I (with the USA, Italy, Poland and Iceland being the only significant exceptions). ${ }^{6}$

Model III includes additional output/outcome variables to PISA scores, i.e. school enrolment (secondary) and teacher-pupil ratio (secondary). According to this model there are two additional efficient nations, i.e. Belgium and Poland. Interestingly, the biggest improvement in the ranking is shown by Denmark, with one of the highest levels of school enrolment (secondary) averages accounting for around 125\% in the 1999-2007 period (the EU/OECD average is around $106 \%$ ). In order to become an efficient nation, selected countries should significantly increase the level of their PISA scores (particularly in Romania), the level of their school enrolment (secondary) (particularly in highly populated countries, such as Korea and the USA), and the teacher-pupil ratio (secondary) (in Japan, Sweden and the UK).

In terms of the efficiency scores for ICT in Model IV, up to 12 of the analysed countries are labelled efficient (see Table 4). The average output efficiency score is 1.01511 , meaning that the average country could increase its outputs/outcomes by around $1.5 \%$ if it were efficient. The worst efficiency performers are Italy, the USA and the UK, with the last two having well above-average ICT expenditures and Internet users (per 100 people) and well below-average PISA scores (in the USA), school enrolment (primary and secondary) (in the USA) and school

\footnotetext{
${ }^{6}$ These ranking changes resulted from the relatively high level of labour force with a tertiary education (in the USA and Iceland) and relatively small number of Internet users (in Italy and Poland).
} 
enrolment (tertiary) (in the UK). On the other hand, Italy has below-average levels of its inputs and outputs/outcomes and therefore an increase in ICT expenditures and Internet users alongside a significant efficiency improvement is needed in the county. Indeed, all three countries should increase their outputs by $4.4 \%$ to 7.9 in order to become an efficient.

Table 4: DEA results for ICT efficiency in selected OECD and EU countries

\begin{tabular}{|c|c|c|c|c|c|c|c|c|c|}
\hline No. & Country & \multicolumn{2}{|c|}{ Model I } & \multicolumn{2}{|c|}{ Model II } & \multicolumn{2}{|c|}{ Model III } & \multicolumn{2}{|c|}{ Model IV } \\
\hline & & VRSTE & Rank & VRSTE & Rank & VRSTE & Rank & VRSTE & Rank \\
\hline 1 & Australia & 1.06339 & 7 & n.a. & n.a. & n.a. & n.a. & n.a. & n.a. \\
\hline 2 & Austria & 1.10092 & 13 & 1.06040 & 13 & 1.05115 & 21 & 1.03784 & 22 \\
\hline 3 & Belgium & 1.08288 & 9 & 1.01999 & 7 & 1.00000 & 1 & 1.00000 & 1 \\
\hline 4 & Bulgaria & 1.32790 & 27 & n.a. & n.a. & 1.00000 & 1 & 1.00000 & 1 \\
\hline 5 & Czech R. & 1.10171 & 14 & 1.00869 & 6 & 1.00596 & 8 & 1.00258 & 13 \\
\hline 6 & Denmark & 1.10320 & 16 & 1.10320 & 21 & 1.01339 & 10 & 1.02449 & 19 \\
\hline 7 & Finland & 1.00000 & 1 & 1.00000 & 1 & 1.00000 & 1 & 1.00000 & 1 \\
\hline 8 & France & 1.12181 & 19 & 1.03470 & 9 & 1.02663 & 18 & 1.01070 & 16 \\
\hline 9 & Germany & 1.09520 & 11 & n.a. & n.a. & 1.02570 & 17 & 1.04204 & 23 \\
\hline 10 & Greece & 1.19124 & 25 & n.a. & n.a. & 1.02556 & 16 & 1.00000 & 1 \\
\hline 11 & Hungary & 1.12273 & 20 & 1.08677 & 19 & 1.02372 & 14 & 1.02153 & 18 \\
\hline 12 & Iceland & 1.11989 & 18 & 1.00000 & 1 & 1.02275 & 13 & 1.01361 & 17 \\
\hline 13 & Italy & 1.17995 & 24 & 1.05702 & 12 & 1.11064 & 25 & 1.07881 & 26 \\
\hline 14 & Japan & 1.06834 & 8 & 1.08181 & 18 & 1.04171 & 20 & 1.03091 & 21 \\
\hline 15 & Korea & 1.02025 & 4 & 1.06586 & 15 & 1.00656 & 9 & 1.00000 & 1 \\
\hline 16 & Netherlands & 1.06163 & 6 & 1.06163 & 14 & 1.03030 & 19 & 1.00000 & 1 \\
\hline 17 & $\begin{array}{l}\text { New } \\
\text { Zealand }\end{array}$ & 1.05411 & 5 & 1.04909 & 11 & 1.00000 & 1 & 1.02618 & 20 \\
\hline 18 & Norway & 1.01909 & 3 & 1.00000 & 1 & 1.00000 & 1 & 1.00000 & 1 \\
\hline 19 & Poland & 1.10506 & 17 & 1.00507 & 5 & 1.00000 & 1 & 1.00000 & 1 \\
\hline 20 & Portugal & 1.17397 & 23 & 1.07200 & 16 & 1.05337 & 22 & 1.00000 & 1 \\
\hline 21 & Romania & 1.31120 & 26 & 1.18268 & 22 & 1.10368 & 24 & 1.00293 & 1 \\
\hline 22 & Slovakia & 1.00000 & 1 & 1.00000 & 1 & 1.00000 & 1 & 1.00000 & 1 \\
\hline 23 & Slovenia & 1.09282 & 10 & 1.02316 & 8 & 1.02193 & 12 & 1.00473 & 15 \\
\hline 24 & Spain & 1.16046 & 22 & 1.04906 & 10 & 1.01584 & 11 & 1.00000 & 1 \\
\hline 25 & Sweden & 1.09620 & 12 & 1.09620 & 20 & 1.02507 & 15 & 1.00000 & 1 \\
\hline 26 & UK & 1.10181 & 15 & 1.07618 & 17 & 1.07807 & 23 & 1.04406 & 24 \\
\hline 27 & USA & 1.14787 & 21 & 1.00000 & 1 & 1.12480 & 26 & 1.05256 & 25 \\
\hline \multicolumn{2}{|c|}{$\begin{array}{l}\text { Number of } \\
\text { efficient } \\
\text { countries }\end{array}$} & \multicolumn{2}{|l|}{2} & \multicolumn{2}{|l|}{5} & \multicolumn{2}{|c|}{7} & \multicolumn{2}{|c|}{12} \\
\hline \multicolumn{2}{|c|}{ Mean } & 1.11199 & & 1.04928 & & 1.03103 & & 1.01511 & \\
\hline \multicolumn{2}{|c|}{ Std. dev. } & $\begin{array}{r}0.07830 \\
9\end{array}$ & & $\begin{array}{r}0.04508 \\
4\end{array}$ & & $\begin{array}{r}0.03603 \\
7\end{array}$ & & $\begin{array}{r}0.02118 \\
1\end{array}$ & \\
\hline
\end{tabular}

Note: Relative efficiency scores (models I-IV; see Table 2). Twenty-seven countries are included in the analysis (Mexico is excluded as an outlier).

Sources: World Bank, 2011; UNESCO, 2011; OECD, 2010; own calculations.

According to the above empirical analysis, it is obvious that the use of ICT in many of the countries considered suffers from relatively low technical efficiency. This inefficiency is particularly highlighted in some highly developed OECD members, i.e. the USA, the UK and Austria (see Table 5). Since all of these countries use significantly above-average ICT resources, it will be crucial for them to increase their educational outputs and outcomes. On the other hand, Italy, France and Hungary reveal low efficiency despite using a relatively low level of ICT inputs. Hence, an improvement of the efficiency of ICT, which could 
significantly contribute to a country's stronger development and growth should therefore be a top priority in the near future for most countries, particularly those in the third and fourth quartiles.

Table 5: Relative Efficiency of ICT in Selected OECD and EU countries (Distribution by quartiles of the ranking of efficiency scores in three models)

\begin{tabular}{|c|c|c|c|}
\hline $1^{\text {st }}$ quartile & $2^{\text {nd }}$ quartile & $3^{\text {rd }}$ quartile & $4^{\text {th }}$ quartile \\
\hline Finland & Netherlands & Greece & Hungary \\
Slovakia & New Zealand & Denmark & France \\
Norway & Sweden & Portugal & Austria \\
Belgium & Bulgaria & Iceland & UK \\
Korea & Spain & Japan & USA \\
Poland & Czech R. & Germany & Italy \\
& Slovenia & Romania & \\
\hline
\end{tabular}

Note: Relative efficiency scores (models I - IV; see Table 2). Twenty-seven countries are included in the analysis.

Sources: World Bank, 2011; UNESCO, 2011; OECD, 2010; own calculations.

\section{CONCLUSIONS}

The empirical results show that the efficiency of ICT, when taking educational outputs/outcomes into consideration, differs significantly across the great majority of EU and OECD countries. The analysis of the varying levels of (output-oriented) efficiency (under the VRS framework) shows that Finland, Norway, Belgium and Korea are the most efficient countries in terms of their ICT sectors (when considering educational output/outcome). The empirical results also suggest that, in general, some less developed EU countries such as Slovakia and Poland show a relatively high level of ICT efficiency due to the low level of their ICT inputs. Therefore, a significant increase in ICT expenditures is needed in those countries. All in all, the analysis finds evidence that most of the countries under consideration hold great potential for increased efficiency in ICT and for improving their educational outputs and outcomes.

However, a few limitations of the presented empirical study should be pointed out. Firstly, the application of the presented techniques is hampered by a lack of suitable data. Quality data are called for because the techniques available to measure efficiency are sensitive to outliers and may be influenced by exogenous factors. Secondly, the precise definition of inputs, outputs and outcomes may significantly influence the results. Finally, it seems important to bear in mind that by using a non-parametric approach, and in spite of DEA being an established and valid methodology, differences across countries are not statistically assessed 
and this may be considered a limitation of the methodology. Hence, further research is clearly needed to eliminate the above deficiencies, in particular to test the influence of environmental factors on ICT efficiency.

\section{REFERENCES}

Afonso, A., \& St. Aubyn, M. (2005). Non-parametric approaches to education and health efficiency in Oecd countries. Journal of Applied Economics, 8(2): 227-246.

Afonso, A., \& St. Aubyn, M. (2006a). Cross-country efficiency of secondary education provision: a semi-parametric analysis with non-discretionary inputs. Economic Modelling, 23(3): 476-491.

Afonso, A., \& St. Aubyn, M. (2006b). Relative efficiency of health provision: a DEA approach with non-discretionary inputs. ISEG-UTL, Department of Economics Working Paper $n^{\circ} 33 / 2006 / \mathrm{DE} / \mathrm{UECE}$.

Amjad, R. 2006. Why Pakistan must break-into the knowledge economy. Lahore Journal of Economics, Special Edition, September 2006.

Bailey, S. J. (2002). Public Sector Economics: Theory, Policy and Practice. London: Palgrave Macmillan.

Balanskat, A., Blamire, R., \& Kefala, S. (2006). The ICT impact report: a review of studies of ICT impact on schools in Europe. Brussels: European Schoolnet.

Becta. (2006). The Becta Review 2006: Evidence on the progress of ICT in education', UK: Becta. Retrieved $\quad$ March $01, \quad 2012$ from http://becta.org.uk/corporate/publications/documents/The_Becta_Review_2006.pdf

Chalos, P. (1997). An examination of budgetary inefficiency in education using data envelopment analysis. Financial Accountability \& Management, 13(1): 55-69.

Charnes, A., Cooper, W., \& Rhodes, E. (1978). Measuring efficiency of decision-making units. European Journal of Operational Research, 33: 429-444.

Clements, B. (2002). How efficient is education spending in Europe? European Review of Economics and Finance, 1: 3-26.

Coelli T., Rao, D., \& Battese, G. (2002). An introduction to efficiency and productivity analysis. 6th edition, Massachusetts, Kluwer Academic Publishers.

Cox, M., J., \& Marshall, G. M. (2007). Effects of ICT: do we know what we should know?', Education and Information Technologies, 12: 59-70.

Empirica. (2006). Benchmarking access and use of ICT in European schools 2006. Bonn: Empirica. $\quad$ Retrieved $\quad$ February $02, \quad 2012$ from http://www.empirica.com/publikationen/documents/No08-2006_learnInd.pdf

Fuchs, T., \& Woessmann, L. (2004). Computers and student learning: bivariate and multivariate evidence on the availability and use of computers at home and at school, CESifo Working Paper. No. 1321. November. Munich.

Goolsbee, A., \& Guryan, J. (2002). The impact of internet subsidies in public schools, NBER Working Papers 9090, National Bureau of Economic Research, Inc.

Gülbahar, Y., (2008). ICT usage in higher education: a case study on preservice teachers and instructors, The Turkish Online Journal of Educational Technology, 7(1): 32-37.

Gupta, S., \& Verhoeven, M. (2001). The efficiency of government expenditure: experiences from Africa. Journal of Policy Modelling, 23: 433-467.

Hameed, T. (2006). ICT as an enabler for socio-economic development. Digital Opportunity Forum 2006, International Telecommunication Union, Seoul: Korea. Retrieved January 26, 2012, from http://www.itu.int/osg/spu/digitalbridges/materials/hameed-paper.pdf 
Iqbal, M. J., \& Ahmed, M. (2010). Enhancing quality of education through e-learning: the case study of Allama Iqbal Open University. The Turkish Online Journal of Distance Education, 11(1). Retrieved January 16, 2012 from https://tojde.anadolu.edu.tr/tojde37/articles/article 5.htm

Jafarov, E., \& Gunnarsson, V. (2008). Government spending on health care and education in Croatia: efficiency and reform options; International Monetary Fund; IMF Working Paper; WP/08/136.

Jayson, W. R. (2008). ICT in education reform in Cambodia: problems, politics, and policies impacting implementation. Information Technologies and International Development, 4(4): 67-82.

Johnes, J. (1996). Performance assessment in higher education in Britain. Eur. J. Oper. Res., $89,18-33$.

Kang, M., Heo, H., Jo, I, Shin, J., Seo, J., \& Shin, S. (2008). The new millennium learners and educational performance: the 2 nd year report. Technical report. KERIS

Khan, A. M., \& Shah, Q. A. (2004). Study on impact of information and communication technology on decent work in Pakistan. Islamabad: Pakistan Manpower Institute, Ministry of Labour Manpower \& Overseas Pakistanis, Government of Pakistan.

Kirpatrick, H., \& L. Cuban. (1998). Computers make kids smarter--right? Technos Quarterly for Education and Technology, 7, 2.

Kozma, R. (2003). Technology and classroom practices: an international study, Journal of Research on Technology in Education, 36(1): 1-14.

Kozma, R. B. (2008). Comparative analysis of policies for ICT in education. Center for Technology in Learning, SRI International (to appear in the International Handbook on Information Technology in Education).

Kulik, J. (2003). The effects of using instructional technology in elementary and secondary schools: what controlled evaluation studies say. Menlo Park, CA: SRI International.

Leuven, E., Lindahl, M., Oosterbeek, H., \& Webbink, D. (2004). The effect of extra funding for disadvantaged pupils on achievement. IZA Discussion Paper. No. 1122. Bonn: Institute for the Study of Labor.

Machin, S., McNally, S., \& Silva, O. (2006). New technologies in schools: is there a pay off? London: Centre for Economic Performance; Bonn: Institute for the Study of Labour.

Mandl, U., Dierx A., \& Ilzkovitz, F. (2008). The effectiveness and efficiency of public spending. European Commission, Economic Papers 31, February.

Markovic, R. M. (2009). Education through E-learning: Case of Serbia . Journal of Business Economics and Management, 10(4), 313-319.

OECD. (2010). Education at glance 2010. OECD indicators. Retrieved February 21, 2012 from

http://www.oecd.org/document/52/0,3343,en_2649_39263238_45897844_1_1_1_1,00.ht $\mathrm{ml}$

Ozcan, Y. A. (2007). Health Care Benchmarking and Performance Evaluation: An Assessment using Data Envelopment Analysis (DEA). New York: Springer.

Pelgrum, W.J., \& Anderson, R.A. (Eds) (1999). ICT and the merging paradigm for life-long learning: A worldwide assessment of infrastructure, goals and practices. Amsterdam: International Association for the Evaluation of Educational Achievement.

Shaheeda, J., Dick, N., \& Laura, C. (2007). The role of ICTs in higher education in South Africa: One strategy for addressing teaching and learning challenges. International Journal of Education and Development using Information and Communication Technology. 3(4): 131-142. 
Shaikh, Z. A. (2009). Usage, acceptance, adoption, and diffusion of information and communication technologies in higher education: a measurement of critical factors. Journal of Information Technology Impact (JITI), 9(2): 63-80.

Shaikh, Z., A., \& Khoja, S. A. (2011). Role of ICT in shaping the future of Pakistani higher education system. The Turkish Online Journal of Educational Technology, 10(1): 149161.

St. Aubyn, M. (2003). Evaluating efficiency in the Portuguese education sector. Economia, $26,25-51$.

Tondeur, J., van Braak, J., \& Valcke, M. (2007). Towards a typology of computer use in primary education. Journal of Computer Assisted Learning, 23, 197-206.

Trucano, M. (2005). Knowledge maps: ICT in education, Washington, DC: infoDev/World Bank.

Unesco. (2011). Data centre, Montreal: UNESCO Institute for Statistics, On-line.

Verma, A., \& Gavirneni, S. (2006). Measuring police efficiency in India: an application of data envelopment analysis. Policing: An International Journal of Police Strategies \& Management, 29(1): 125-145.

World Bank. (2011). World development indicators, On-line.

Youssef, B., A., \& Dahmani, M. (2008). Student's performances and ICTs, University and Knowledge Society Journal (RUSC), March 2008, 45-56.

Yusuf, M. O., \& Afolabi, A. O. (2010). Effects of computer assisted instruction (cai) on secondary school students' performance in biology. The Turkish Online Journal of Educational Technology, 9(1): 62-69. 